Baumann-Grace, J. B. \& Tomcsik, J. (1957). J. gen. Microbiol. 17, 227-237

\title{
The Surface Structure and Serological Typing of Bacillus megaterium
}

\author{
By J. B. BAUMANN-GRACE AND J. TOMCSIK \\ Institute for Hygiene and Bacteriology, University of Basel, Sritzerland
}

\begin{abstract}
SUMMARY: The surface structures and serological typing of 54 strains of Bacillus megaterium were examined and compared with strain $M$. Morphologically the strains could be divided into 2 groups on the basis of cell size, fat content and susceptibility to enzymes. Forty homologous immune sera were prepared in rabbits. On the basis of the capsular and cell-wall reactions, 38 distinct serological types were found. The arrangement of the polysaccharide and polypeptide material in the capsules is described. Agglutination reactions confirmed the heterogeneity of the polysaccharides in the cell wall and capsules of $B$. megaterium and demonstrated a further relationship between 3 of the strains, probably due to the flagellar antigen. Precipitin reactions carried out with the supernatant fluid from broth cultures or with cellwall extracts showed a much broader specificity.
\end{abstract}

An unusual complex capsular structure showing a topographically distinct localization of D-glutamic acid polypeptide and a type-specific polysaccharide was first demonstrated in strain $M$ of Bacillus megaterium (Tomcsik, 1951), designated in previous studies as Bacillus ' $M$ '. The discovery that lysozyme induces a spherical transformation of the protoplasts of this strain led to the demonstration of the specific cell-wall reaction (Tomcsik \& Guex-Holzer, 1952). It was also shown that, contrary to previous observations, the cytoplasm of these bacilli could be digested with trypsin. The resulting cytoskeleton consists mainly of the cell wall and also gives a microscopically visible specific reaction with the homologous immune serum (Tomcsik \& Guex-Holzer, 1954 $a, b$; Tomcsik \& Grace, 1955; Tomesik \& Baumann-Grace, 1957). These trypsin-treated bacteria, when inoculated into rabbits, produced antibodies which reacted with the cell wall and with the polysaccharide components of the capsule but not with the isolated protoplasts. In contrast, antibodies produced by the isolated protoplasts reacted with the thermolabile trypsinsensitive component of the bacterial surface as well as with the protoplasts themselves, but serologically were completely distinct from the cell wall and capsule (Tomcsik \& Guex-Holzer, 1954b). Thus Bacillus megaterium strain $\mathbf{M}$ proved to be exceptionally well-suited to enzymic and serological investigation as well as to the study of antibodies as cytological indicators (Tomcsik, 1956). These results obtained with $B$. megaterium strain $M$ showed that several cytologically-definable elements of the cell structure, namely the two capsular materials, the thermolabile antigen of non-capsulated bacteria, the cell wall and the isolated protoplasts could be used for serological typing. Although some of the observations described above were confirmed with one or two authentic strains of $\boldsymbol{B}$. megaterium, their application to the species as a whole was unknown. We have attempted, here, therefore, a serological study of the surface structures of $\boldsymbol{B}$. megaterium. 


\section{METHODS}

Organisms. Forty-five strains of Bacillus megaterium were isolated from soil and examined together with the ' $M$ ' strain (Tomcsik, 1949) and 9 laboratory strains received from Dr J. P. Aubert, Institut Pasteur, Paris (1), Dr C. Weibull, Stockholm (KM strain), Dr S. Raffel, Stanford University, California (2) and Dr Ruth Gordon, Rutgers University, New Brunswick (5).

Isolation of organisms. Ten g. soil were shaken with $100 \mathrm{ml}$. sterile physiological saline. After standing to allow the large particles to sediment, $2 \mathrm{ml}$. of the cloudy supernatant fluid were removed and heated at $80^{\circ}$ for $20 \mathrm{~min}$. After cooling, 2 loopfuls were spread over the surface of a plate of Gladstone \& Fildes CCY agar (Gladstone \& Fildes, 1940) and incubated 20-24 hr. at $28^{\circ}$. Organisms from the various colony types were examined with a phasecontrast microscope and those characteristic of Bacillus megaterium and $B$. cereus purified by plating.

Identification of strains. Bacillus megaterium strains were identified and separated from $B$. cereus according to the data given by Smith, Gordon \& Clark (1952), using mannitol fermentation, the V.P. test and egg-yolk reaction (L.V.; McGaughey \& Chu, 1948) as the main criteria. All the soil strains produced spores at least on isolation and their morphology was noted. In addition, the ability of the strains to produce polypeptide capsules was examined.

Media. All strains were maintained on Gladstone \& Fildes CCY agar. Liquid cultures were obtained in Gladstone \& Fildes CCY broth either by aeration or by shaking in the $T$ tubes described by Kay \& Fildes (1950).

Fat staining. The fat content of the organisms was judged after staining with Sudan Black B, by the method described by Burdon (1946). Carbol fuchsin (1/40) was substituted for safranin in the counterstaining.

Phase-contrast preparations were made as described by Tomcsik \& GuexHolzer (1954a).

Immune sera. The D-glutamic acid polypeptide antibody was that described previously (Tomcsik \& Guex-Holzer, 1954 $a, b$ ). The homologous antibodies against whole organisms, cell walls or protoplasts of the ' $M$ ' and other strains of $\boldsymbol{B}$. megaterium were produced by the intravenous inoculation of rabbits with 6-10 doses of the suspensions at 3- to 4-day intervals. The animals were bled 10 days after the last injection.

Agglutination reactions. The mixtures of antigen and antibody were incubated at $37^{\circ}$ for $10 \mathrm{~min}$., then centrifuged for $4 \mathrm{~min}$. and the test read immediately after shaking up the sediment.

Precipitation reactions. Ring precipitation reactions were carried out with the supernatant fluid obtained after centrifuging $14 \mathrm{hr}$. T-tube shake cultures, or with extracts of trypsin-digested bacteria (see below).

Trypsin digestion. Whole organisms from agar or broth cultures were suspended in physiological saline and the density adjusted to give a reading of c. 180 on the Klett Summerson photoelectric colorimeter, with blue filter no. 42. Three vol. of organisms were added to 1 vol. of $1 \%(w / v)$ trypsin 
(Siegfried, Zofingen) in saline. The $\mathrm{pH}$ value was adjusted to 8.2 with phenolphthalein and $2 \%(\mathrm{w} / \mathrm{v}) \mathrm{Na}_{2} \mathrm{CO}_{3}$; chloroform was added as preservative. After 14-20 hr. incubation, the cell remains were centrifuged and resuspended in saline. Extracts for the precipitation reaction were prepared as follows: the trypsin-digested organisms were supended in either 1/8000 crystalline lysozyme (Armour) in saline, $1 \%(\mathrm{w} / \mathrm{v})$ sodium taurocholate in distilled water or in $0.25 \mathrm{~N}-\mathrm{HCl}$. The digestions were allowed to proceed for $1 \mathrm{hr}$. at $37^{\circ}$ (lysozyme at room temperature) after which the cell-wall remains were removed by centrifugation and the supernatant fluid used in the precipitation reaction. The hydrochloric acid extract was neutralized before testing.

Lysozyme digestion was carried out by the methods described by BaumannGrace \& Tomesik (1957) with crystalline lysozyme (Armour).

\section{RESULTS}

\section{Characteristics of the Bacillus megaterium strains}

Both the freshly-isolated and the laboratory strains corresponded to the descriptions given by Smith et al. (1952) and gave mostly typical biochemical reactions, although 3 strains (1 laboratory strain and 2 isolates) did not ferment mannitol even after continued subculture on the medium. The strains could be broadly divided into two morphological groups. Those designated as group A were large, $c .1 \cdot 2-1 \cdot 5 \mu$. or more in diameter and contained large amounts of fat, often filling the entire organism; about $43 \%$ of the isolates belonged to this type. In contrast, those strains allocated to group B possessed usually rather narrower cells, $c .0 \cdot 9-1 \cdot 2 \mu$. in diameter, and contained very little lipid material which was usually concentrated at the edge of the organism or at the cross-septa giving the appearance of a cell-wall stain with Sudan Black B. Only occasionally were small discrete globules detected in the phase-contrast microscope or after staining. Contrary to the recommendation of Smith et al. (1952) the use of glucose agar did not significantly increase the amount of fat in most of the group B strains. In addition groups A and B differed in their sensitivity towards lysozyme and trypsin, group B strains being on the whole considerably more readily digested by both enzymes than group $\mathbf{A}$ strains (Tomcsik \& Baumann-Grace, 1956; Baumann-Grace \& Tomcsik, 1957). Sporulation was observed in all our isolates from soil. Two morphologically interesting strains were found. In one laboratory strain, the culture consisted of very long filaments in which very few cross-walls could be detected, and in one isolate abnormal division with longitudinal cross-septa was occasionally. observed.

\section{Serological reactions of strain $M$}

Twenty rabbits were immunized with 8-10 intravenous injections of living organisms of strain $M$ and the serological reactions of the best (M15) and three average sera (M3, M 4, M 16) from this series are summarized in Table 1. All 20 immune sera elicited the specific capsular reaction. On addition of serum to the capsulated organisms of strain $\mathbf{M}$ obtained from agar cultures, the capsular transverse septa and the polar caps were rendered visible immediately 
and the margin of the capsule was indicated by a weak radial striation (Pl. 1, fig. 1). The antibody eliciting this reaction could be absorbed with isolated capsular mucopolysaccharide (Guex-Holzer \& Tomesik, 1956). Application of antiserum obtained by the immunization of rabbits with heatkilled Bacillus anthracis, on the other hand, reacted only with the polypeptide part of the capsule of strain $M$ organisms, revealing a homogeneous structure. The gaps expected on the place of the polysaccharide transverse septa were not usually visible in the phase-contrast microscope, probably because of their comparatively small size; only by modifying the cultural conditions was it possible to demonstrate a striated structure (Tomesik \& Guex-Holzer, 1954a). The fact that none of the homologous anti-M sera contained polypeptide antibody, whereas the latter is produced in at least $50 \%$ of the immune sera prepared against $B$. anthracis, suggests that in $B$. megaterium the D-glutamic acid polypeptide occurs only in the haptenic form, in contrast to $B$. anthracis.

Non-capsulated cells of strain $M$ were obtained from an 8-20 hr. aerated or shaken broth culture in which there was little chain formation and the single organisms were usually motile. A specific cell-wall reaction could be elicited on these organisms after trypsin digestion; the titre was usually similar to that of the specific capsular reaction.

Table 1. Serological reactions of anti-M immune sera produced in rabbits against whole bacteria, cell walls and protoplasts

$\begin{array}{clccccc}\begin{array}{c}\text { No. of } \\ \text { immune }\end{array} & \begin{array}{c}\text { Immune serum } \\ \text { against }\end{array} & \begin{array}{c}\text { Specific } \\ \text { capsular } \\ \text { reaction }\end{array} & \begin{array}{c}\text { Specific } \\ \text { cell-wall } \\ \text { reaction }\end{array} & \begin{array}{c}\text { living } \\ \text { bacteria }\end{array} & \begin{array}{c}\text { cell } \\ \text { walls }\end{array} & \begin{array}{c}\text { pgglutinin } \\ \text { protoplasts }\end{array} \\ \text { M3 } & \text { Living bacteria } & +++ & +++ & 1280 & \mathbf{2 4 0} & \text { n.e. } \\ \text { M4 } & \text { Living bacteria } & +++ & +++ & 640 & 120 & \text { n.e. } \\ \text { M15 } & \text { Living bacteria } & ++++ & ++++ & \mathbf{2 5 6 0} & \mathbf{6 4 0} & \mathbf{3 2 0} \\ \text { M16 } & \text { Living bacteria } & +++ & +++ & 960 & 120 & \text { n.e. } \\ \text { M14 } & \text { Cell walls } & + & ++ & 160 & \mathbf{8 0} & \text { neg. } \\ \text { M31 } & \text { Cell walls } & ++ & ++ & 640 & 320 & 1: 20 \\ \text { M32 } & \text { Cell walls } & ++ & ++ & \mathbf{3 2 0} & \mathbf{1 6 0} & 1: 20 \\ \text { M33 } & \text { Cell walls } & +++ & +++ & 640 & 320 & 1: 20 \\ \text { M23 } & \text { Protoplasts } & - & - & 320 & \text { neg. } & 160 \\ \text { M26 } & \text { Protoplasts } & - & - & 640 & \text { neg. } & 320 \\ \text { M27 } & \text { Protoplasts } & - & - & 640 & \text { neg. } & 320 \\ \text { M28 } & \text { Protoplasts } & - & - & 1280 & \text { neg. } & 640\end{array}$

$-=$ no reaction with undiluted serum;,,,$++++++++++=$ visible reactions with $1 / 2,1 / 5,1 / 10$, or $1 / 20$ diluted serum; neg. = no agglutination in $1 / 20$ serum dilution; n.e. $=$ not examined.

All the immune sera prepared against trypsin-treated organisms and protoplasts of strain $\mathbf{M}$ are included in Table 1. Specific cell-wall or capsular reaction was not elicited by the protoplast sera, showing that these entities are serologically distinct. The non-capsulated living bacteria were, on the other hand, agglutinated in varying degree by all three types of immune sera. Further examination of the reaction of the protoplast antibodies and cell-wall antibodies with whole bacteria revealed that two components were involved 
in the agglutination, differing from one another in their sensitivity towards trypsin. The protoplast immune sera agglutinated the intact, non-capsulated bacteria because of a thermolabile trypsin-sensitive component on the surface of the latter which was easily removed in $15-30 \mathrm{~min}$. by simple shaking. There is evidence to suggest that this antigen is probably flagellar material; it is interesting that it is still present on the intact protoplasts after complete digestion of the cell wall with lysozyme in isotonic sucrose solution (Weibull, 1953). On the basis of the data summarized in Table 1 , it is not possible to distinguish between the antibodies which react with the flagella and those which react with the protoplast proper. These results show that the thermolabile surface antigen as well as the thermostable capsular and cell-wall polysaccharides must be taken into consideration in a serological study of the various types of Bacillus megaterium.

\section{Serological typing of Bacillus megaterium, based on the specific capsular and cell-wall reactions}

The typing of the remaining 54 strains of Bacillus megaterium was carried out as follows. Immune sera to five selected strains of $\boldsymbol{B}$. megaterium were prepared by the immunization of rabbits with whole organisms, using one rabbit for each strain. The resulting sera were used to carry out the specific capsular and/or cell-wall reaction on each of the 55 strains. Strains giving even a slight reaction were eliminated and, from those remaining, 5 were selected for immunization and the tests repeated. In this way homologous sera against 40 strains were prepared with which a total of 2255 cross-reactions for the phase-contrast study of the specific capsular reaction were performed. On the basis of these cross-reactions further similarities were found in 3 pairs of strains; all the remaining immune sera apparently contained separate type antibodies. Thus, including strain M, 37 different serological type antisera were obtained which gave a specific capsular reaction with 51 of the 55 strains. More than 300 specific cell-wall reactions were carried out crosswise, which demonstrated the serological parallelism between the specific cell-wall reaction and the capsular reaction which was observed in strain $M$. With the help of the specific cell-wall reaction (Pl. 1, figs. 2, 3) it was possible to demonstrate the relationship between two hitherto untyped strains which gave no capsular reaction because of loss of capsule. Thus, with the help of both reactions, 38 distinct serological types were obtained. It should, however, be emphasized that some of the cross-reactions were weak, indicating that some of the strains were similar but not identical; when these are omitted, the number of distinct types is even higher.

Tabulation of the serological reactions of all the strains would require too much space and only a few of the more interesting cross-reactions may be mentioned. Two serologically identical strains were of geographically distant origin, one being isolated in the U.S.A. and one in Switzerland. Four of the laboratory strains contained serologically similar capsular and cell-wall substances. One of these strains was obtained from the Pasteur Institute, Paris, two from Dr Raffel, Stanford University (one of which was designated 
originally as Bacillus tumescens) and one from Dr Weibull (Stockholm). The last mentioned strain KM has been used in most of the protoplast studies (Weibull, 1956; McQuillen, 1956) and is uncapsulated, but it gives with the immune sera prepared against the 'Paris' strain, as well as with the serum against one of our own isolates, a strong specific cell-wall reaction. Considering the large number of serological types found in $B$. megaterium it seems possible therefore that these four old laboratory strains giving similar specific capsular and cellwall reactions have a common origin.

Since so many serological types were found, it was of interest to examine the typical complex capsular structure to see whether the capsule characteristic of strain $\mathbf{M}$ occurred with any regularity in the other strains and whether other morphological arrangements of the polysaccharide and polypeptide are to be found. A capsular structure, entirely similar to that described in strain $\mathrm{M}$ was found in 10 of the strains of Bacillus megaterium (PI. 1, fig. 1). Morphologically all resembled strain $\mathbf{M}$ and belonged to group $\mathbf{B}$ (the narrower cells). Repeated examinations of these 10 strains revealed always the same regular arrangment of the capsular polysaccharides. In a few cases, however, abundant production of capsular polypeptide prevented the diffusion of the polysaccharide antibody and caused a capsular refraction. Four of these strains together with strain $\mathbf{M}$ were examined by Dr C. Weibull (personal communication) with regard to their cytochrome systems, and were found to be identical. The arrangement of the capsular polysaccharide in 12 other strains was similar but less typical. Transverse septa were found only on a few division levels; more frequently a thickening of the polysaccharide occurred at the points of division and at the poles, giving a bamboo-like appearance to the chains. Only 7 of these strains were 'narrow-celled' and belonged to group B. One of these was also examined by Dr Weibull with regard to its cytochrome system and was found to be identical with that of strain M. Five strains belonging to morphological group $\mathbf{A}$ showed a distinct comb-like structure with homologous antiserum ( $\mathrm{Pl}$. 2, fig. 4a,b). The units of this structure were similar in size and showed no additional thickening at the division level. The remainder of the strains possessed a thin, almost homogeneous polysaccharide capsule on the cell wall, and in some cases it was possible to demonstrate that it was surrounded by a layer of polypeptide in such a way that the capsular substances were concentrically arranged (Pl. 2, figs. 5, 6).

Application of Bacillus anthracis polypeptide antiserum elicited a polypeptide capsular reaction in 53 of the 55 B. megaterium strains. Two old laboratory cultures no longer gave a polypeptide reaction. All 45 strains obtained from soil possessed a well-defined polypeptide capsule shortly after isolation, in contrast to the remaining old laboratory strains in which only a thin polypeptide layer was detected. It was observed that several of the freshly isolated strains lost much of this material after continued transfer on agar medium, which suggests that polypeptide production is a characteristic of strains of $\boldsymbol{B}$. megaterium living in soil. The polypeptide capsule more often appears homogeneous than striated, even in 13 strains of group B which 
showed typical capsular transverse septa with homologous serum. Only 14 of the 53 strains gave a comb-like reaction.

The possibility that a third material existed in the capsule was demonstrated in one strain in which the polysaccharide antibody of strain $\mathbf{M}$ elicited a marginal reaction of the capsule whereas addition of homologous antibody demonstrated only the interior layer (Pl. 2, figs. 7, 8). Polypeptide antibody reacted with the exterior region of the capsule.

\section{Serological typing of Bacillus megaterium, based on the agglutination reaction}

In previous studies on strain $M$ of Bacillus megaterium it was observed that large capsules tended to inhibit the agglutination reaction, and for this reason the reactions summarized in Table 1 were carried out with non-capsulated bacilli. With strain $M$ the latter could always be obtained from aerated or shaken broth cultures, but unfortunately these methods of cultivation did not totally prevent capsule formation in most of the other strains. However, satisfactory agglutination reactions were obtained with 41 of the sera which with the homologous strains gave titres ranging from $1 / 160$ to $1 / 2500$. The non-specific agglutination titre was found to be 1/10 or less. In order to simplify the technique of carrying out cross-reactions between 41 sera and 55 strains, the preliminary agglutination tests were performed with a serum dilution of $1 / 100$, thus eliminating some of the weaker side-reactions. The same major cross-reactions were disclosed by the agglutination test as were observed by the specific capsular and cell-wall reactions. Only one additional crossreaction was observed. Strain $\mathbf{M}$ showed hardly any relationship to the other B. megaterium strains in the morphological reactions, but cross-reacted with one strain (Mg 50) and showed a more distant relationship to a second (Mg 49) in the agglutination tests. The observations leading to the elucidation of these reactions are summarized in Table 2.

Table 2. Serological relationship of the Bacillus megaterium strains $M, M g 49$ and $M g 50$

\begin{tabular}{|c|c|c|c|c|c|c|}
\hline \multirow[b]{2}{*}{$\begin{array}{c}\text { Immune sera } \\
\text { against }\end{array}$} & \multirow[b]{2}{*}{ Strain } & \multicolumn{5}{|c|}{ Agglutination titre of sera agains } \\
\hline & & $\begin{array}{c}\text { Specific } \\
\text { capsular } \\
\text { reactions }\end{array}$ & $\begin{array}{l}\text { Specific } \\
\text { cell-wall } \\
\text { reactions }\end{array}$ & $\begin{array}{c}\text { living } \\
\text { bacteria }\end{array}$ & $\begin{array}{c}\text { trypsin } \\
\text { digested } \\
\text { bacteria }\end{array}$ & $\begin{array}{c}\text { shaken } \\
\text { bacteria }\end{array}$ \\
\hline $\begin{array}{l}\text { Strain M } \\
\text { Cell wall }\end{array}$ & $\begin{array}{l}\text { M } \\
\text { Mg 49 } \\
\text { Mg 50 }\end{array}$ & $\begin{array}{c}++ \\
\pm \\
-\end{array}$ & $\begin{array}{c}++ \\
- \\
-\end{array}$ & $\begin{array}{l}160 \\
\cdot\end{array}$ & $\begin{array}{l}160 \\
\cdot \\
.\end{array}$ & $\begin{array}{l}160 \\
\cdot \\
.\end{array}$ \\
\hline Protoplast & $\begin{array}{l}\text { M } \\
\text { Mg 49 } \\
\text { Mg } 50\end{array}$ & $\begin{array}{l}- \\
-\end{array}$ & $\begin{array}{l}- \\
-\end{array}$ & $\begin{array}{c}1280 \\
\dot{1280}\end{array}$ & $\dot{.}$ & $\dot{.}$ \\
\hline $\begin{array}{c}\text { Strain Mg } 49 \\
\text { whole bact. }\end{array}$ & $\begin{array}{l}\text { M } \\
\text { Mg 49 } \\
\text { Mg 50 }\end{array}$ & $\stackrel{ \pm}{+}+$ & $\begin{array}{c}- \\
++\end{array}$ & $\begin{array}{l}160 \\
640 \\
160\end{array}$ & 320 & $\dot{320}$ \\
\hline $\begin{array}{c}\text { Strain Mg } 50 \\
\text { whole bact. }\end{array}$ & $\begin{array}{l}\mathrm{M} \\
\mathbf{M g} 49 \\
\mathbf{M g} 50\end{array}$ & $\begin{array}{c} \pm \\
- \\
++\end{array}$ & $\begin{array}{c}\overline{-} \\
+\overline{+}+\end{array}$ & $\begin{array}{c}2560 \\
\dot{2} \\
2560\end{array}$ & $\dot{1280}$ & $\dot{1280}$ \\
\hline
\end{tabular}


Morphological examination confirmed that neither the cell wall nor the capsule were involved in the cross-reactions. The antibody obtained with the cell wall of strain $M$ was strictly specific, but the antibody produced from the protoplasts of this strain cross-agglutinated intact bacteria of strain $\mathbf{M g} 50$ to full titre. Since trypsin digestion or simple shaking for an hour without glass beads abolished the cross-reaction, it was concluded that the 'protoplast antibody' probably reacted with flagellar material.

\section{The serological specificity of substances released into the medium in fluid cultures}

Precipitation reactions were carried out between the culture supernatant fluid of 55 strains and 41 immune sera. The uninoculated medium did not give a precipitation reaction with any of the sera. Contrary to the sharp specificity of the capsular and cell-wall reactions, the culture supernatant fluids of most of the Bacillus megaterium strains gave an unexpectedly large number of cross-reactions. Only type-specific reactions were obtained with trypsintreated bacteria in the specific cell-wall and agglutination reactions. However, after further treatment of these bacteria with lysozyme, sodium taurocholate $(1 \%, \mathrm{w} / \mathrm{v})$ or $0.25 \mathrm{~N}-\mathrm{HCl}$ the extracts showed the same broad specificity in the precipitation reaction as the culture fluids.

\section{DISCUSSION}

The primary purpose of this work was to analyse the surface structures and the serological typing of 55 strains of Bacillus megaterium. Morphological and cytochemical observations showed that the strains of this species may be broadly divided into two groups: group A, those characterized by broad cells and large amounts of fat inclusions; group B, the smaller-celled strains possessing hardly any fat globules. Previous observations (Baumann-Grace \& Tomcsik, 1957) suggested that differences in the cell-wall structure between the two groups exist, since most of the strains belonging to group $\mathbf{A}$ could not be completely digested with lysozyme whereas those of group $\mathbf{B}$ were rapidly and easily dissolved. However, biochemical differences between the two groups were not observed and polypeptide was produced by all strains on isolation, in contradistinction to $B$. cereus (details of this observation will be published elsewhere).

On the basis of the specific capsular reaction, with antisera prepared in rabbits against 40 of the strains, 37 distinct serological types were found. Previous work (Tomesik \& Guex-Holzer, 1951, 1954 a) had shown that these type differences may be assumed to be due to specific polysaccharides. In 11 strains, the homologous sera revealed a capsular structure similar to that originally described in strain $\mathbf{M}$, characterized chiefly by thin cross-septa occurring as a continuation of the cross-walls, and polar caps. These strains belonged entirely to group B. A similar but less typical arrangement was found in 12 other strains. The remainder of the strains (most of which belonged to group A) showed various morphological arrangements of the capsule 
on the addition of homologous antiserum, the most commonly occurring form showing radial striation. A number of strains, particularly those from old laboratory cultures, showed only a thin homogeneous polysaccharide layer surrounding the bacilli and the exterior layer of the capsule could only be detected by applying polypeptide antibody. In those strains which showed striations or transverse septa on addition of polysaccharide antibody, the complementary arrangement of the polypeptide capsular material could only be demonstrated when the polysaccharide 'discs' were sufficiently thick.

The specific cell-wall reaction performed with trypsin-treated bacteria completely confirmed the type distribution found by the capsular reaction. Essentially similar results were also obtained by the normal agglutination technique, thus stressing the major role played by the cell wall in the serological relationship of Bacillus megaterium. In the few discrepancies observed with the agglutination reaction, it was found that the cell walls were serologically distinct and that the cross-agglutination was probably due to the similarity of the flagellar antigen. The problem why antibodies against the flagella are formed when a protoplast suspension deprived of cell-wall material is used for immunization, remains to be solved.

The results of the specific capsular and cell-wall reactions, as well as of the agglutination tests, justify the conclusion that the intact capsules and cell walls of Bacillus megaterium exhibit a very large number of serological types, greater, in fact, than any other species studied up to the present. Thus it is surprising to find that the bacteria-free culture fluids from $15 \mathrm{hr}$. cultures or extracts of cell walls showed a much broader specificity, giving rise to many more cross-reactions. The reason for this is not clear, but it may be suggested that either the autolytic and chemical breakdown products of the capsular and cell-wall polysaccharides are less specific or that these processes liberate polysaccharides with a broader specificity from the deeper layers of the cell wall and which are normally not involved in the specific morphological and agglutination reactions.

The use of serological typing in the identification of vegetative Bacillus megaterium is not practicable owing to the large number of serological types encountered. In fact, as many as five distinct types were isolated from one single soil sample. The possession of a capsule which contains both polypeptide and polysaccharide material showing a distinct morphological arrangement seems to be a characteristic of the species and might be used in classification. For identification purposes, however, the strains should be examined for capsule production soon after isolation, as experience has shown that this character tends to diminish or to be completely lost on continued subculture.

This work was aided by a grant from the Swiss Federal Labour Office (Bern). 


\section{REFERENCES}

Baumann-Grace, J. B. \& Tomcsik, J. (1957). Lysozym-Empfindlichkeit der Species B. megaterium. Experientia, 13, 148.

Burdon, K. L. (1946). Fatty material in bacteria and fungi revealed by staining dried, fixed slide preparations. J. Bact. 52, 665 .

Gladstone, G. P. \& Findes, P. (1940). A simple culture medium for general use without meat extract or peptone. Brit. J. exp. Path. $21,161$.

Guex-Holzer, S. \& Tomcsik, J. (1956). The isolation and chemical nature of capsular and cell-wall haptens in a Bacillus species. J. gen. Microbiol. 14, 14.

KAY, D. \& Fildes, P. (1950). The calcium requirements of a typhoid bacteriophage. Brit. J. exp. Path. 31, 338.

McGaughey, C. A. \& ChU, H. P. (1948). The egg-yolk reaction of aerobic sporing bacilli. J. gen. Microbiol. $2,834$.

McQuillen, K. (1956). Capabilities of bacterial protoplasts in Bacterial Anatomy. Symp. Soc. gen. Microbiol., 6, 126.

Smith, N. R., Gordon, R. E. \& Clark, F. E. (1952). Aerobic sporeforming bacteria. Agric. Mongr. no. 16.

Tomcsik, J. (1949). Zur Frage der induzierten Mutation der Milzbrandbazillen. Schweiz. Z. Path. 12, 498.

Tomcsik, J. (1951). Complex structure of the bacterial capsule in the genus Bacillus. Experientia, 7, 459.

Tomcsik, J. (1956). Antibodies as indicators for bacterial surface structures. Annu. Rev. Microbiol. 10, 213.

Tomcsik, J. \& Grace, J. B. (1955). The specific cell-wall reaction and staining of the bacterial cell wall with Alcian blue. J. gen. Microbiol. 13, 105.

Tomcsik, J. \& Baumann-Grace, J. B. (1956). Zellwandfreie Bakterienprotoplasten. Verh. naturf. Ges. Basel. 67, 218.

Tomcsik, J. \& Baumann-Grace, J. B. (1957). Wirkung des Trypsins auf die Bakterienzellstruktur. Schweiz. Z. Path. 20, 129.

Tomcsik, J. \& Guex-Holzer, S. (1951). Anthrax-Polypeptid und andere speziesspezifische Substanzen der Kapsel in der Bazillus-Gruppe. Schreiz. Z. Path. 14, 515.

Tomcsik, J. \& Guex-Holzer, S. (1952). Änderung der Struktur der Bakterienzelle im Verlauf der Lysozym-Einwirkung. Schweiz. Z. Path. 15, 517.

Tomcsik, J. \& Guex-Holzer, S. (1954a). A specific cell-wall reaction in Bacillus sp. J. gen. Microbiol. 10, 317.

TomcsIK, J. \& GuEx-Holzen, S. (1954b). Antikörperproduktion mit isolierter Bakterienzellwand und mit Protoplasten. Experientia, 10, 484.

Weibuld, C. (1953). The isolation of protoplasts from Bacillus megaterium by controlled treatment with lysozyme. J. Bact. 66, 688.

Weibuli, C. (1956). Bacterial protoplasts; their formation and characteristics in Bacterial Anatomy. Symp. Soc. gen. Microbiol., 6, 111.

\section{EXPLANATION OF PLATES}

All figures: bacteria from Gladstone-Fildes agar cultures examined by phase-contrast microscopy at $\times \mathbf{2 0 0 0}$.

\section{Plate 1}

Fig. 1. Strain $M$ after addition of homologous immune serum.

Fig. 2. B. megaterium strain No. 1 after treatment for $7 \mathrm{hr}$. with 1/400 trypsin. The cell wall is faintly visible without antibody.

Fig. 3. The same microscopical field as in fig. 2 after the addition of homologous antibody. 
Journal of General Microbiology, Vol. 17, No. 1

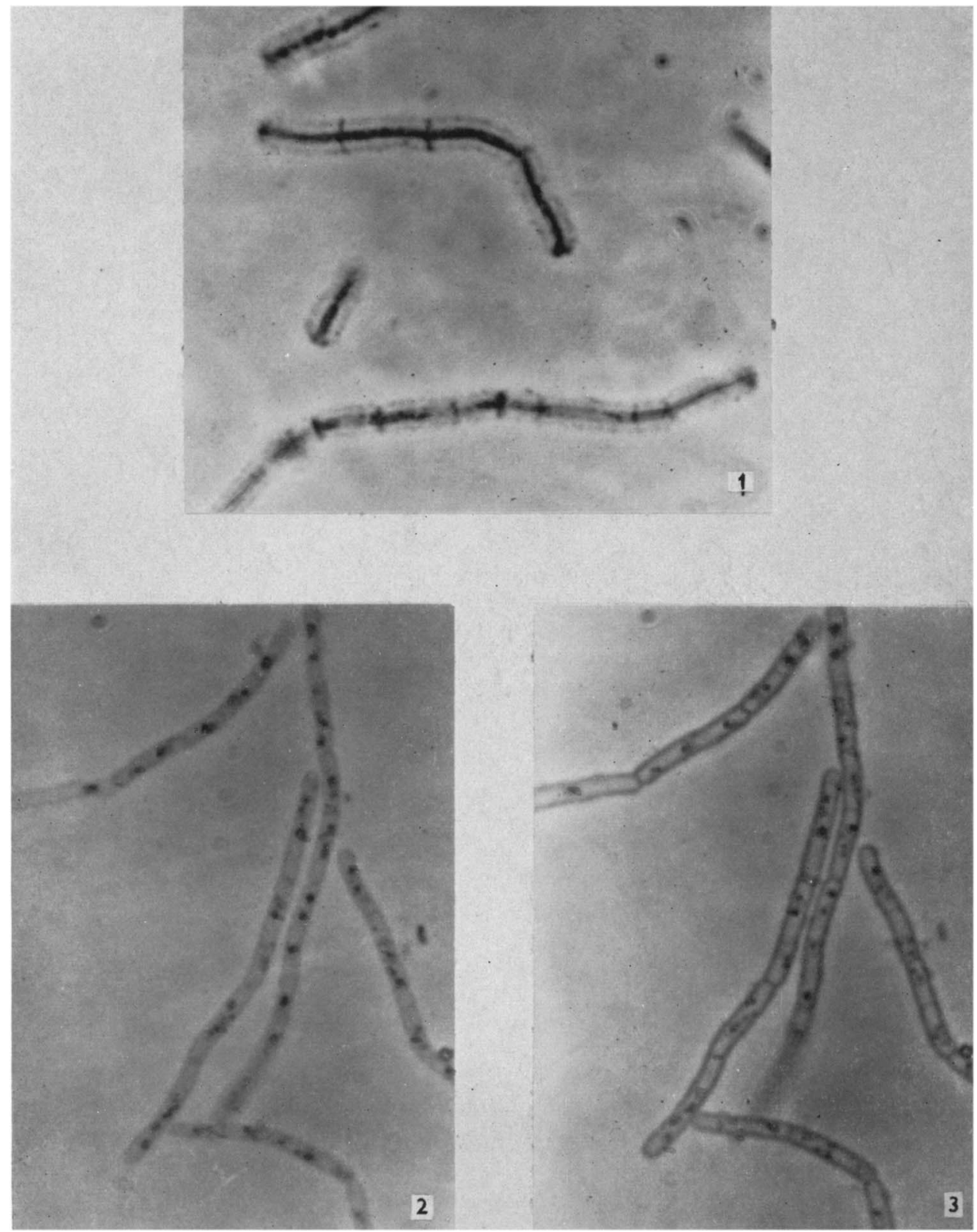

J. B. Baumann-Grace and J. Tomcsik-The surface of B. megaterium. Plate 1 
Journal of General Microbiology, Vol. 17, No. 1
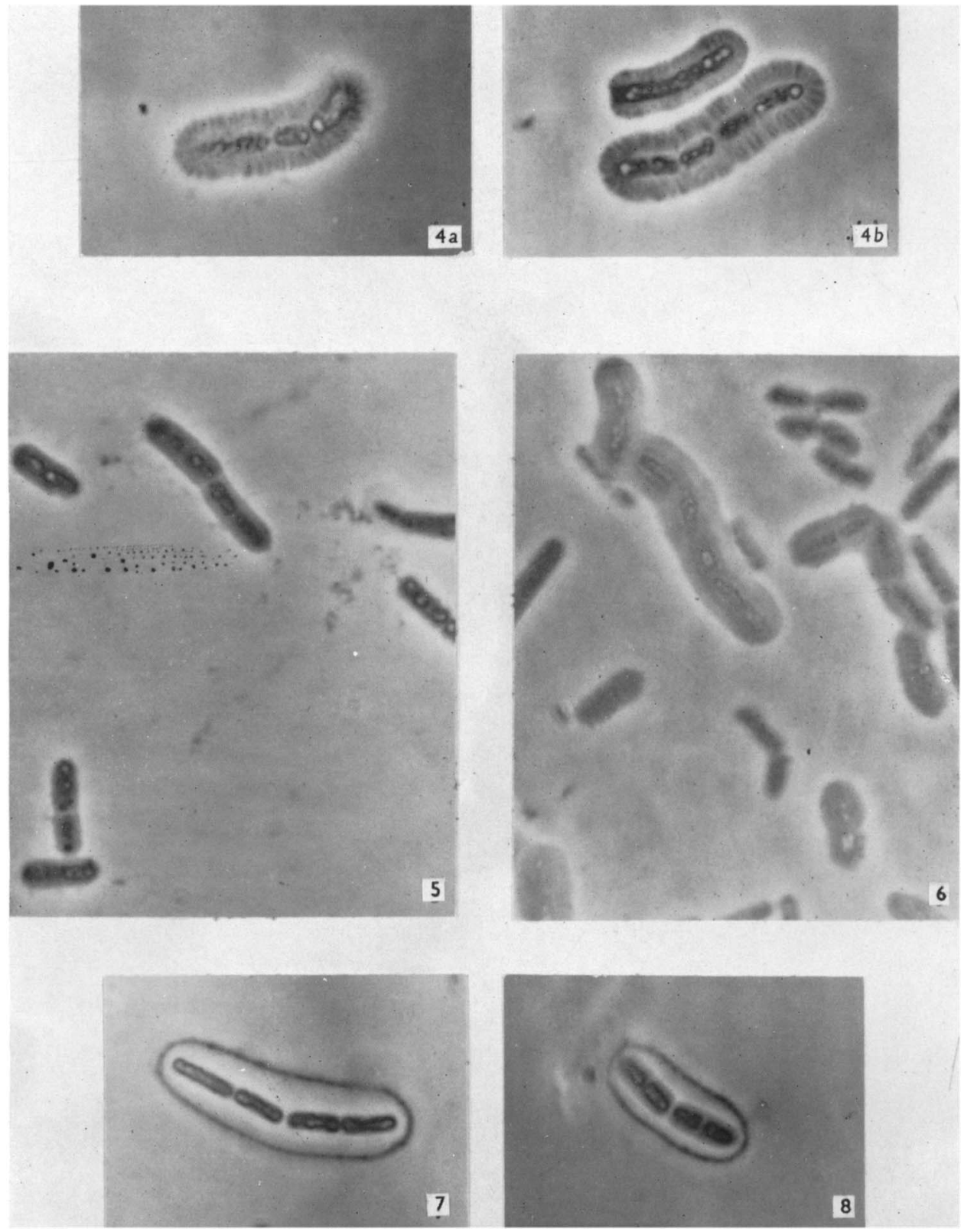

J. B. Baumann-Grace and J. Tomcsik-The surface of B. megaterium. Plate 2 


\section{The surface of $\mathrm{B}$. megaterium}

Prate 2

Fig. $4 a, b . B$. megaterium strain no. 21 after addition of homologous immune serum. A comb-like capsular structure is revealed.

Fig. 5. B. megaterium strain no. 2 together with the homologous antibody; the interior layer of the capsule is revealed.

Fig. 6. The same preparation as in fig. 5, after successive addition of anthrax-polypeptide antibody. The exterior layer of the capsule is now revealed.

Fig. 7. B. megaterium strain no. 49 after addition of strain $M$ anti-serum. The heterologous antibody reacts only with the surface layer of the capsule.

Fig. 8. The same preparation as in fig. 7, after addition of the homologous immune serum. The interior layer of the capsule reacts with the homologous antibody.

(Received 11 March 1957) 